\title{
ARTICLE \\ Subfunctionalization of cation/proton antiporter 1 genes in grapevine in response to salt stress in different organs
}

\author{
Yuanchun Ma ${ }^{1}$, Jiaoyang Wang ${ }^{1}$, Yan Zhong ${ }^{1}$, Fang Geng ${ }^{1}$, Grant R Cramer $^{2}$ and Zong-Ming (Max) Cheng ${ }^{1,3}$
}

Cation/proton antiporter 1 (CPA1) proteins function as regulators of monovalent ions, pH homeostasis, and other developmental processes in plants. Better understanding of the expression and regulation of CPA 1 in plant responses to salinity would help the development of scientific practices in crops worldwide. In this report, we characterized all seven CPA 1 family genes in grapevine (Vitis vinifera) in response to short-term osmotic and $\mathrm{NaCl}$ stresses. We found that two of the seven genes have subfunctionalized to be differentially expressed in response to $\mathrm{NaCl}$ stress in the early stage in different organs, whereas the other five members seem to play little or no role in this response. Specifically, VIT_19s0090g01480 may control $\mathrm{Na}^{+}$compartmentalization in grapevine roots; and VIT_05s0020g01960 may influence $\mathrm{Na}^{+}$transfer in stems. Based on the dynamics of ion concentrations, electrolyte leakage rates, and CPA1 gene expression in root, stem, and leaf tissues under osmotic and $\mathrm{NaCl}$ stresses, we suggest how grapevine responds physiologically and molecularly to the osmotic and ion toxicity of $\mathrm{NaCl}$ stress in the short term. This work lays a foundation for future research on the CPA1 gene family regarding its evolutionary history and biological functions for modulating salt responses in grapevine.

Horticulture Research (2015) 2, 15031; doi:10.1038/hortres.2015.31; Published online: 15 July 2015

\section{INTRODUCTION}

Salinity is one of the major abiotic stresses that limits plant growth worldwide. ${ }^{1}$ More than $50 \%$ of all arable land is predicted to suffer serious salinization by the year 2050 because of salinity and drought effects. ${ }^{2}$ Salt stress primarily disrupts the homeostasis of the water potential and the ion distribution within the plant. ${ }^{3}$ High salinity causes damage to plants by water deficit due to osmotic stress and by ion toxicity from excessive $\mathrm{Na}^{+} .{ }^{4,5}$ Therefore, separating the effects of ion toxicity from those of osmotic stress caused by excess salinity is vital to understanding the mechanism of salt tolerance in plants. Plants can resist or tolerate salinity stress by maintaining a low $\mathrm{Na}^{+}$concentration in the cytoplasm, such as by reducing $\mathrm{Na}^{+}$influx, increasing $\mathrm{Na}^{+}$efflux, or by $\mathrm{Na}^{+}$compartmentalization. ${ }^{6,7}$

In plants, a low $\mathrm{Na}^{+}$concentration in the cytoplasm is primarily maintained by the cation/proton antiporter (CPA) superfamily, which is one of the cation transporter families. ${ }^{8}$ The CPA proteins, which contain a conserved $\mathrm{Na}^{+} / \mathrm{H}^{+}$exchanger domain, are associated with transporting monovalent cations across membranes. As secondary active transporters, CPAs function primarily as couplers of the efflux of diverse cations with inward movement of $\mathrm{H}^{+} ., 10$

Grapevine (Vitis vinifera L.) has been domesticated for approximately 8000 years ${ }^{11}$ and is one of the world's most important fruit crops. In 2010, it was grown on approximately 7.1 million hectares. $^{12}$ Grapevine is adapted to semiarid environments, where drought and salinity are common problems. Grapevine is considered moderately tolerant to salinity stress, ${ }^{13-16}$ and this moderate tolerance has been mainly attributed to salt exclusion or to restriction of toxic ions in the root system. ${ }^{17}$ Studies of grapevine salt tolerance have primarily focused on the selection of salt-tolerant rootstocks, physiological comparison of salt tolerance in different grapevine cultivars, ${ }^{17,18}$ and recently, the development of high throughput assay methods. ${ }^{19}$ The only functional study on the CPA1 gene of grapevine investigated the role of $V v i N H X 1$ in fruit development ${ }^{20}$ rather than on responses to salinity. The grapevine genome contains seven members in the CPA1 gene family (VIT_01s0011g06550, VIT_15s0024g00280, VIT_07s0104g01280, VIT_05s0020g01960, VIT_14s0128g00020,VIT_14s0030g00710, and IT_ $1950090 \mathrm{~g}$ 01480), which are homologous to the Arabidopsis $N H X$ genes (AtNHX1-8), and they have been implicated in grapevine salt tolerance. ${ }^{21,22}$

In this report, we determined the family-wide expression of VViCPA1 genes in response to both osmotic stress and salinity stress and linked it to the physiological responses. Based on the dynamics of ion concentrations, electrolyte leakage rate, and CPA1 gene expression in root, stem, and leaf tissues under osmotic and $\mathrm{NaCl}$ stress for 0-36 h, we suggest a process for the short-term responses to salt in grapevine. This research lays the foundation for further characterization of the grapevine CPA1 subfamily and their roles in the physiological responses to salinity and osmotic stress.

\section{MATERIALS AND METHODS}

Plant material

In vitro grapevine plants $(V$. vinifera genotype PN40024, the sequenced genotype, kindly provided by Dr. Anne-Françoise Adam-Blondon, INRA, France) were cultured in vitro in glass baby food jars $(10 \mathrm{~cm}$ tall, $6 \mathrm{~cm}$ in diameter) on $1 / 2$ Murashige and Skoog salt medium supplemented with 0.3 $\mathrm{mg} \mathrm{L}^{-1}$ indole-3-butyric acid (IBA, Sigma, St. Louis, USA) and $2 \%$ sucrose. The jars were placed under a $16 / 8 \mathrm{~h}$ day/night photoperiod $\left(100 \mu \mathrm{mol} \mathrm{m}^{-2} \mathrm{~s}^{-1}\right)$ between $23{ }^{\circ} \mathrm{C}$ and $25{ }^{\circ} \mathrm{C}$ in a culture room with fluorescent illumination of $125 \mu \mathrm{mol} \mathrm{m}{ }^{-2} \mathrm{~s}^{-1}$. After 45 days, uniform plants were selected as the test material and were transferred into Hoagland solution $(210 \mathrm{ppm} \mathrm{N}, 235 \mathrm{ppm}$ K, 200 ppm Ca, 31 ppm P, 64 ppm S, 48 ppm Mg, 0.5 ppm B, 5 ppm Fe,

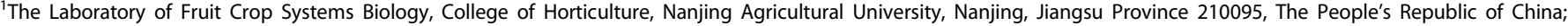

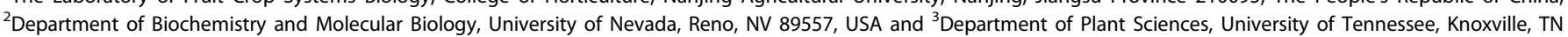
37996, USA
}

Correspondence: ZM Cheng (zmc@njau.edu.cn, zcheng@utk.edu)

Received: 6 May 2015; revised: 4 June 2015; accepted 4 June 2015 
0.5 ppm Mn, 0.05 ppm Zn, 0.02 ppm Cu, 0.01 ppm Mo) ${ }^{23}$ for seven days. The temperature, humidity, and illumination were kept the same as above.

Determination of membrane permeability

To determine the extent of plasma membrane damage, the rate of electrolyte leakage (REL, expressed as \%) was measured. $\mathrm{NaCl}$ was applied to the culture medium at three concentrations: 20,120, and $250 \mathrm{mM}$. After 0 (without adding $\mathrm{NaCl}$, as control), 1, 4, 8, 12, 24, and $36 \mathrm{~h}, 0.5 \mathrm{~g}$ of fresh root and leaf (middle of the plant) tissue were harvested. Root (cut into $1 \mathrm{~cm}$ ) and leaf segments (cut into $1 \mathrm{~cm}^{2}$ ) were completely immersed in vials containing 10 $\mathrm{mL}$ of deionized water and placed into a vacuum $\left(80000 \mathrm{~m}\right.$ Torr) at $25^{\circ} \mathrm{C}$ for $40 \mathrm{~min}$. Then, the vials were set aside in a dark place for $30 \mathrm{~min}$; the electrical conductivity of the solution (EC1) was measured by a conductivity meter (BANTE 950; Shanghai, China).

The vial was then autoclaved at $120{ }^{\circ} \mathrm{C}$ for $20 \mathrm{~min}$, and the electrical conductivity of the solution (EC2) was measured after equilibration to $25{ }^{\circ} \mathrm{C} .24,25$ The relative conductivity (RC) was defined as RC = EC1/EC2. The REL was used as the index of injury and was calculated according to a previous study. ${ }^{26}$

$$
\operatorname{REL}(\%)=100(\mathrm{RCt}-\mathrm{RC}) /(1-\mathrm{RC}) \text {; }
$$

where $\mathrm{RCt}$ is the $\mathrm{RC}$ at a given treatment point $(1,4,8,12,24$, and $36 \mathrm{~h})$ and $\mathrm{RCO}$ is the RC for the control $(0 \mathrm{~h})$.

Determination of plant $\mathrm{Na}^{+}, \mathrm{K}^{+}, \mathrm{Ca}^{++}$, and $\mathrm{Mg}^{++}$concentrations After $\mathrm{NaCl}(250 \mathrm{mM})$ treatment for $0,1,4,8,12,24$, and $36 \mathrm{~h}$, approximately $0.5 \mathrm{~g}$ of fresh root (including root tips) and leaf tissue were harvested and dried thoroughly at $80^{\circ} \mathrm{C}$ for $48 \mathrm{~h}$. The tissue was then ground and digested in concentrated $2 / 1(\mathrm{v} / \mathrm{v}) \mathrm{HNO}_{3} / \mathrm{HClO}_{4}$. The concentrations of $\mathrm{Na}^{+}, \mathrm{K}^{+}, \mathrm{Ca}^{++}$, and $\mathrm{Mg}^{++}$in the samples were then determined by ICP-MS (Iris Intrepid II; Thermo Electron Corporation, Franklin, MA, USA) according to previous studies. $^{27-29}$

Quantitative real-time RT-PCR for grapevine CPA1 genes

Because the impact of salt stress on a plant has two components, osmotic stress and ion toxicity, we employed two treatments in an attempt to separate the effects of osmotic stress and ion toxicity: $\mathrm{NaCl}(250 \mathrm{mM})$, which was found to cause damage within $36 \mathrm{~h}$, and the equivalent osmotic potential obtained using PEG 6000. Both were applied to Hoagland solution. The osmotic potential was determined by a FM-8P automatic freezing point osmometer (Shanghai Medical University Instrument, Shanghai, China) to ensure equal osmolarity of the two solutions. Hoagland solution served as the control solution. The plants were transplanted into Hoagland solution at $23{ }^{\circ} \mathrm{C} / 25{ }^{\circ} \mathrm{C}$ (50\% humidity, 16-h-light/8-h-dark cycle; $700 \mu \mathrm{mol} \mathrm{m}{ }^{-2} \mathrm{~s}^{-1}$ ). Roots, stems (except shoot tip), and leaves (middle of the plant) were harvested after they were treated for $0,1,4,8,12,24$, and $36 \mathrm{~h}$ and then were frozen in liquid nitrogen.

Table 1. Primer sequences used for $\mathrm{QPCR}$ analysis and PCR amplification products

\begin{tabular}{|c|c|c|c|}
\hline Gene & F/R & Primer sequence $\left(5^{\prime} \sim 3^{\prime}\right)$ & $\begin{array}{l}\text { Product } \\
\text { (bp) }\end{array}$ \\
\hline \multirow[t]{2}{*}{ VIT_15s0024g00280 } & $\mathrm{F}$ & CAGCAATAGTTGTTTTGACGGTTTTGTTG & 287 \\
\hline & $\mathrm{R}$ & GTCTTCTTGTTCTTCATCATCTCCAGTTTG & \\
\hline \multirow[t]{2}{*}{ VIT_07s0104g01280 } & $\mathrm{F}$ & AGTACACTGGTGTTTGGCTTGATGAC & 232 \\
\hline & $\mathrm{R}$ & AGTAATGGTGGACGGTATGAGTTGGG & \\
\hline \multirow[t]{2}{*}{ VIT_05s0020g01960 } & $\mathrm{F}$ & AAATGTACCCCGCCCCACCAG & 181 \\
\hline & $\mathrm{R}$ & ACCTTCTCATCGCCATTGACCAAG & \\
\hline \multirow{2}{*}{ VIT_14s0128g00020 } & $\mathrm{F}$ & CGACACAGGACTCTGCCCTAATG & 236 \\
\hline & $\mathrm{R}$ & GTTACTTGCCTTTGGACTTGGTTGATTG & \\
\hline \multirow[t]{2}{*}{ VIT_14s0030g00710 } & $\mathrm{F}$ & TTTCCCACGCCCTAGTAGCCTTC & 295 \\
\hline & $\mathrm{R}$ & AACGCATTCTCATCAGCCACACC & \\
\hline \multirow[t]{2}{*}{ VIT_19s0090g01480 } & $\mathrm{F}$ & CGTGTAGAGATCAGTCTGCCTGCTAG & 168 \\
\hline & $\mathrm{R}$ & CCAATGCTGTGCTGTCTCCAACTATAAC & \\
\hline \multirow[t]{2}{*}{ VIT_01s0011g06550 } & $\mathrm{F}$ & ACTCCAAGGTACACCACACACAAAAG & 170 \\
\hline & $\mathrm{R}$ & GATGGGTACAATCATAATGCTGTAGAACG & \\
\hline
\end{tabular}

a

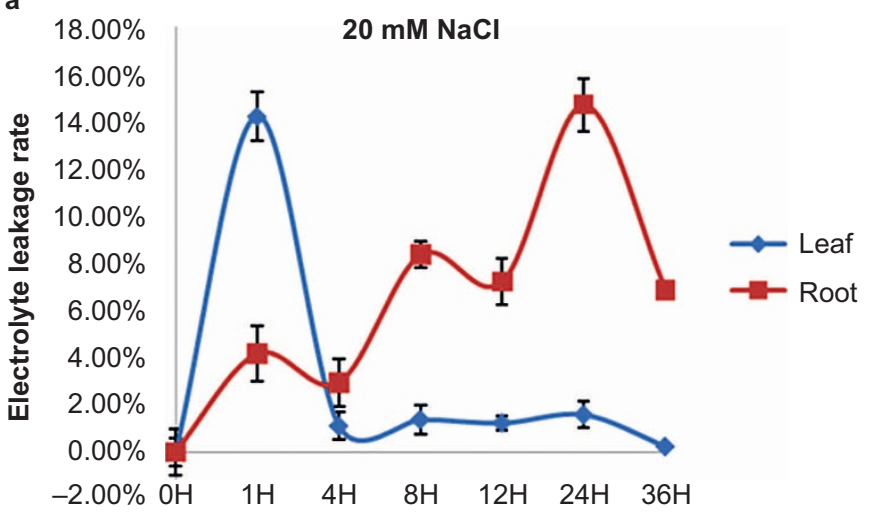

b

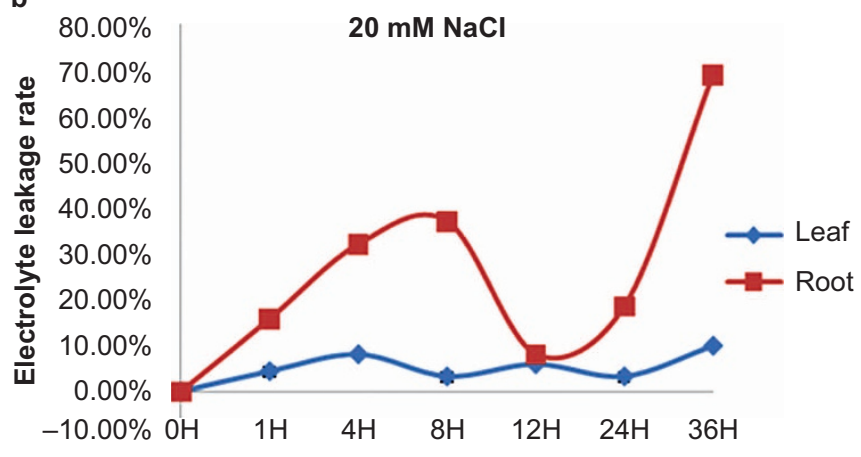

c

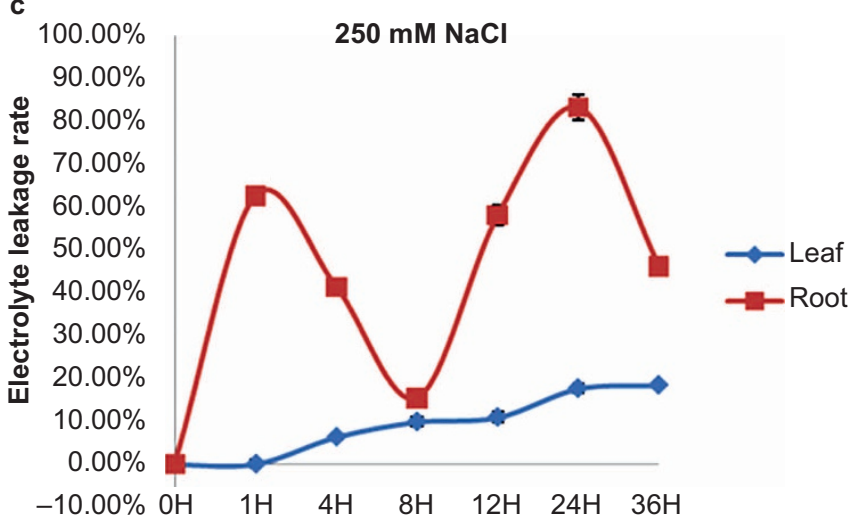

Figure 1. Changes in the rate of electrolyte leakage (REL) in roots and in leaves, after treatment at three $\mathrm{NaCl}$ concentrations. (a) $20 \mathrm{mM}$, (b) $120 \mathrm{mM},(\mathbf{c}) 200 \mathrm{mM}$. The values indicate the mean $\pm \mathrm{SD}(n=3)$.

Total RNA was extracted from the frozen samples using a protocol with cetyltrimethylammonium bromide (CTAB) and lithium chloride precipitation, 30,31 and then the RNA was purified with RNase-free DNase I (TaKaRa, Dalian, China). The concentration of RNA was measured with a One Drop TM OD-1000 spectrophotometer (Thermo Fisher Scientific, Waltham, USA), and purity was determined by the optical density (OD) absorption ratio OD 260 $\mathrm{nm} / \mathrm{OD} 280 \mathrm{~nm}$. RNA integrity was monitored by electrophoresis on $1.0 \%$ agarose gels by staining with ethidium bromide. For CDNA synthesis, high quality total RNA was reverse transcribed with oligdT and random primers using the PrimeScript RT reagent Kit (TaKaRa, Dalian, China). The first-strand CDNA samples were stored at $-20^{\circ} \mathrm{C}$ before being examined as templates.

Gene-specific primers for the grapevine CPA1 genes were designed according to the predicted mRNA sequences using Beacon Designer 7.0 software (Premier Biosoft International, CA, USA). To certify the specificity of the primers, all of the primers had at least one nucleotide difference in 
the $3^{\prime}$-end of the open reading frame and were tested with PCR amplification and gel electrophoresis. The PCR amplification products were sequenced at least three times, and the maximum deviation was less than 3 base pairs. The sequences of the primers and their products are listed in Table 1.

For the quantitative real-time RT-PCR (qPCR) assay, the method has been described in detail previously by our lab..$^{32}$ In brief, cDNA was diluted with

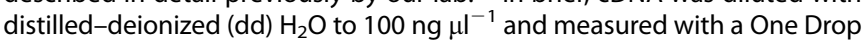
TM OD-1000 spectrophotometer to determine the transcript concentration of each sample. qPCR reactions were performed with SYBR Premix Ex TaqTM (TaKaRa Code: DRR420A, TaKaRa, Dalian, China) on an ABI PRISM 7300 Realtime PCR System (Roche, Penzberg, Germany). A house-keeping gene (actin101-like, VIT_12s0178g00200) was used as an internal control for $\mathrm{qPCR}^{33}$ which was previously used in our lab as a reliable internal reference gene. ${ }^{32}$ Each qPCR reaction was performed in a total volume of $20 \mu$ including $1 \mu$ l of template, $10 \mu \mathrm{l}$ SYBR Premix Ex TaqTM, $0.2 \mu \mathrm{l}$ of each primer, and $8.6 \mu \mathrm{l}$ $\mathrm{ddH}_{2} \mathrm{O}$. The PCR was performed as follows: denaturation for 4 min at $95{ }^{\circ} \mathrm{C}$, followed by 40 cycles of $95{ }^{\circ} \mathrm{C}$ for $20 \mathrm{~s}, 60^{\circ} \mathrm{C}$ for $20 \mathrm{~s}$, and $72{ }^{\circ} \mathrm{C}$ for $43 \mathrm{~s}$. A
A
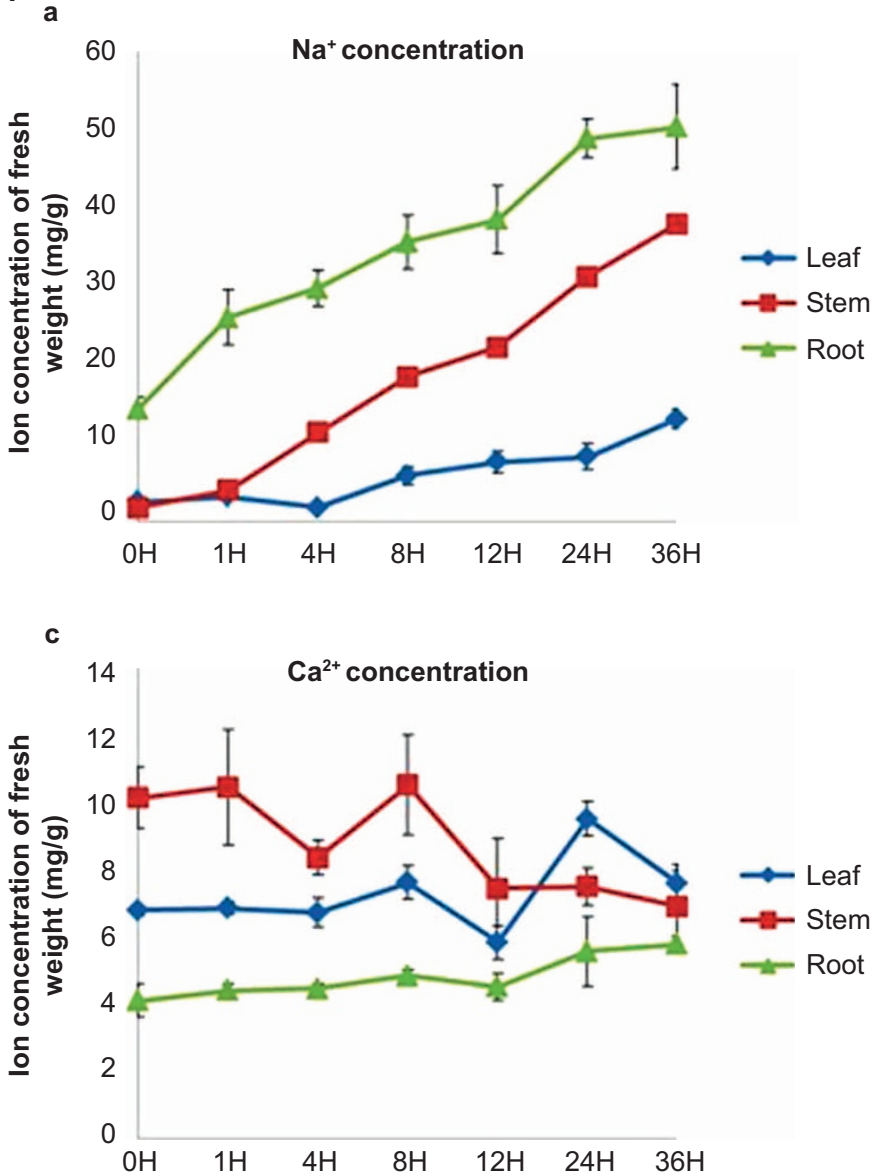

B

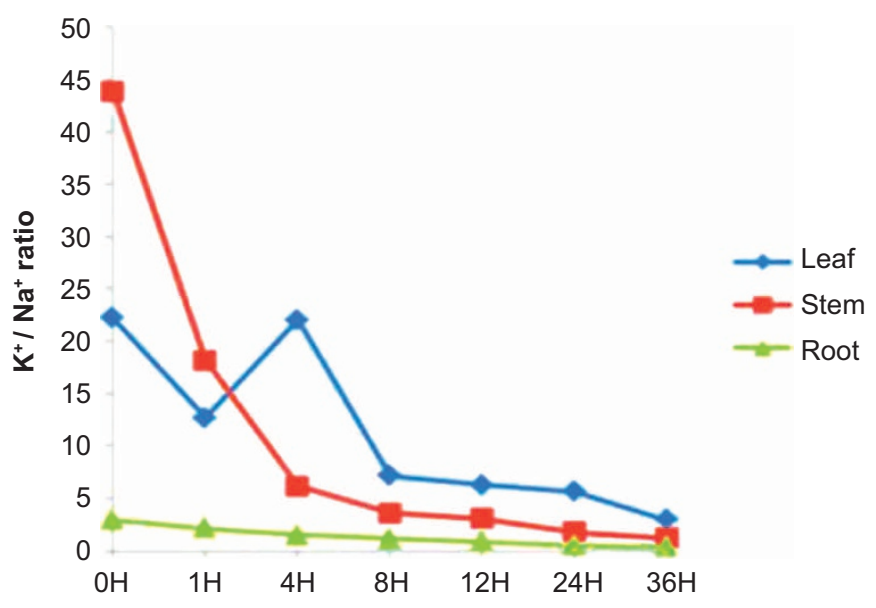

b

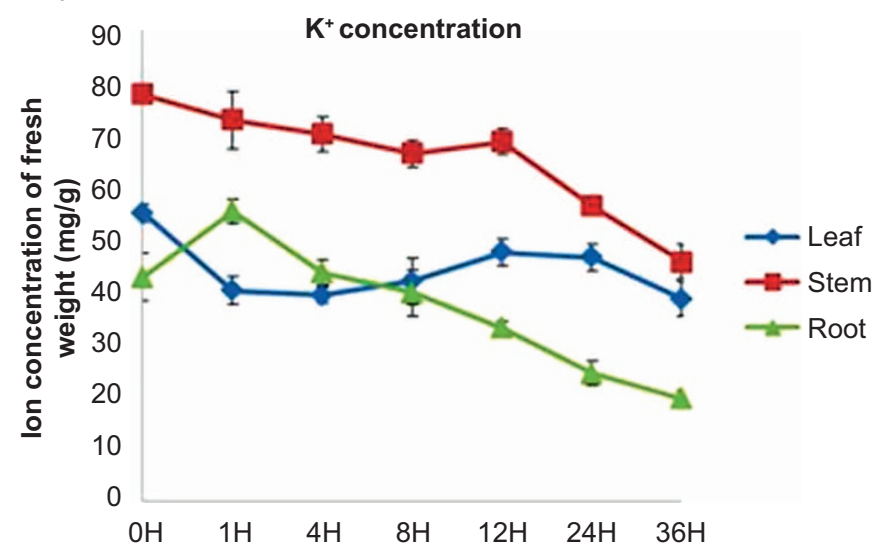

d

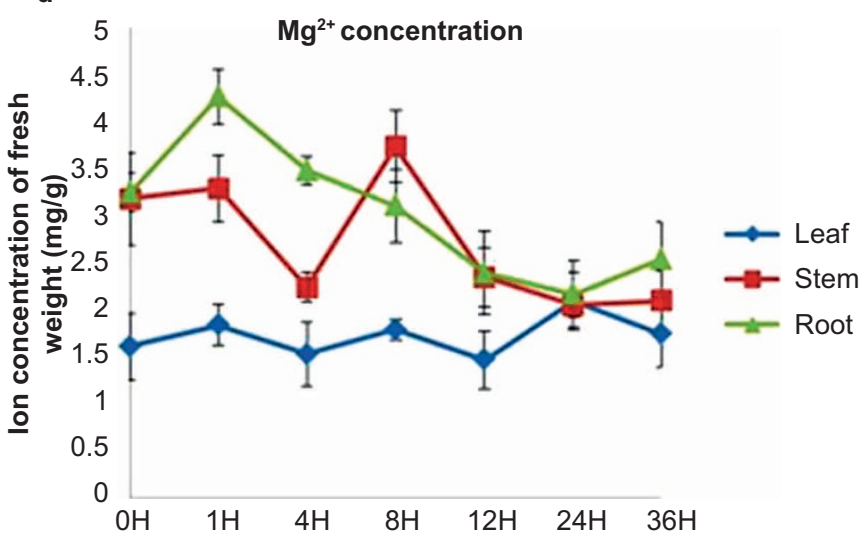

Figure 2. The effects of $250 \mathrm{mM} \mathrm{NaCl}$ on concentrations of ions in different tissues. (A) Of ions concentrations in different tissues. (B) The ratio of $\mathrm{K}^{+} / \mathrm{Na}^{+}$in different tissues. The values indicate the mean $\pm \mathrm{SD}(n=3)$. 

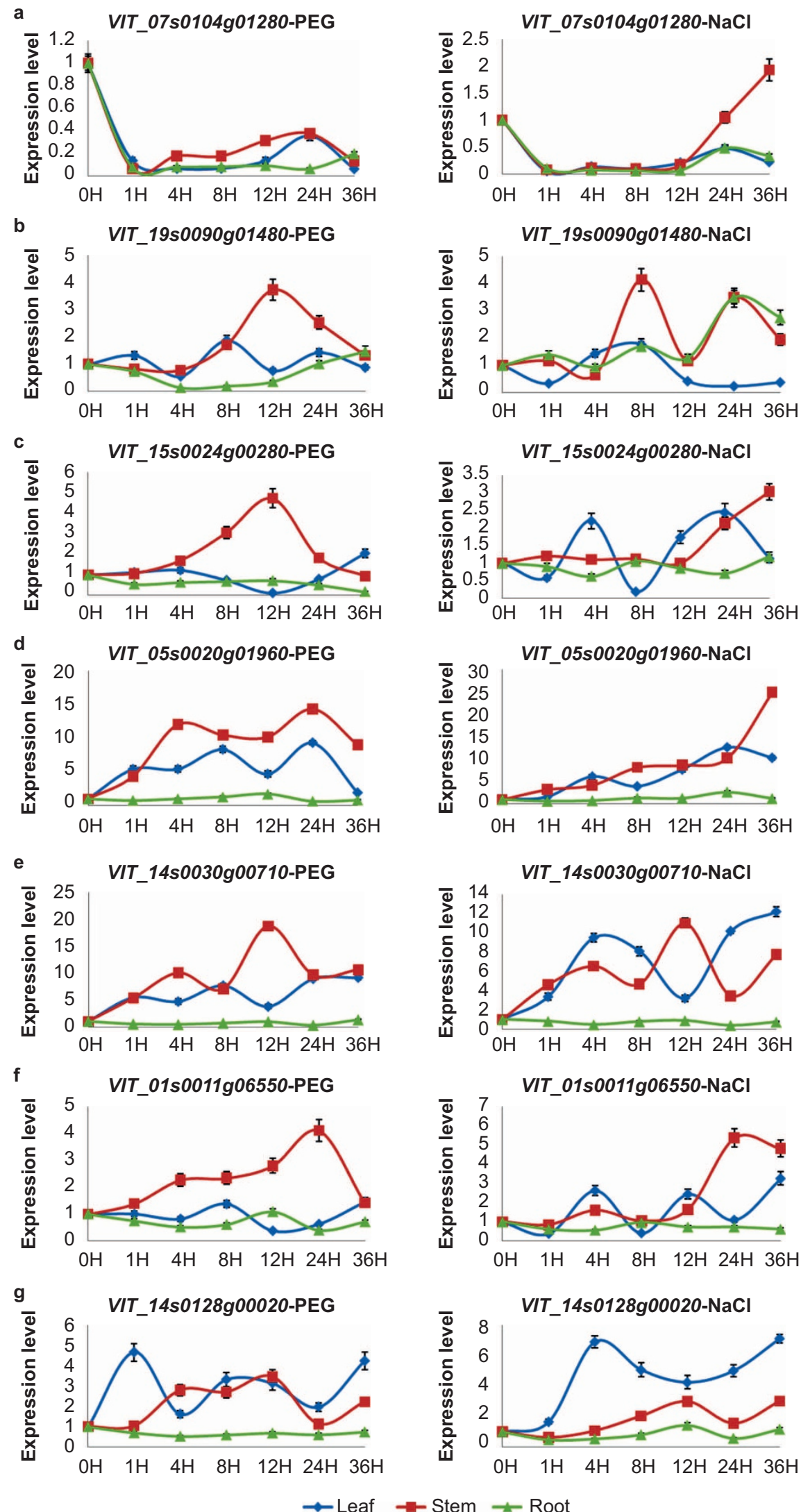

Figure 3. qPCR analysis of the expression of $V v i C P A 1$ genes in grapevine leaves, stems, and roots in response to PEG and NaCl. The data are expressed as the mean \pm SD $(n=3)$. 
negative control reaction without a template was always included for each primer combination. All reactions were performed in triplicate. Three biological replicates were performed for each time point. The qPCR data were analyzed according to $2^{-\Delta \Delta \mathrm{Ct}}$ method, where control

$$
\begin{aligned}
\Delta \Delta C t= & (C t \cdot \text { target gene }-C t \cdot \text { actin }) \cdot \text { treatment } \\
& -(C t \cdot \text { target gene }-C t \cdot \text { actin }) \cdot \text { control }
\end{aligned}
$$

The error bars represent the standard deviation of the mean. ${ }^{34}$

\section{Statistical analysis}

All data were obtained from three independent experiments with three biological replicates, if applicable. Statistical analyses were performed using the software SPSS (Statistical Package for the Social Sciences) version 13.0 (Chicago, IL, USA) and Excel.

\section{RESULTS AND DISCUSSION}

Relative electrolyte leakage rate

Membrane permeability can be measured using the rate of REL, which was determined as described by Lutts and Blum. ${ }^{24,25}$ Figure 1 shows that the extent of change in REL in roots was greater than that in leaves among the three different $\mathrm{NaCl}$ concentrations. During $\mathrm{NaCl}$ stress, defense mechanisms of the root may start when the $\mathrm{NaCl}$ concentration reaches a critical threshold, thus helping prevent leaf damage. From 0 to $4 \mathrm{~h}$ in $20 \mathrm{mM} \mathrm{NaCl}$ (Figure 1a), the REL in leaves was greater than that in roots. However, from 4 to $24 \mathrm{~h}$ in $20 \mathrm{mM} \mathrm{NaCl} ; 4$ to $8 \mathrm{~h}, 12$ to $24 \mathrm{~h}$ in $120 \mathrm{mM} \mathrm{NaCl}$ (Figure $1 \mathrm{~b}$ ); and 0 to $1 \mathrm{~h}, 8$ to $24 \mathrm{~h}$ in $250 \mathrm{mM} \mathrm{NaCl}$ (Figure 1c), the REL increased drastically in roots and gently decreased in leaves. When the $\mathrm{NaCl}$ accumulation reached a critical threshold a
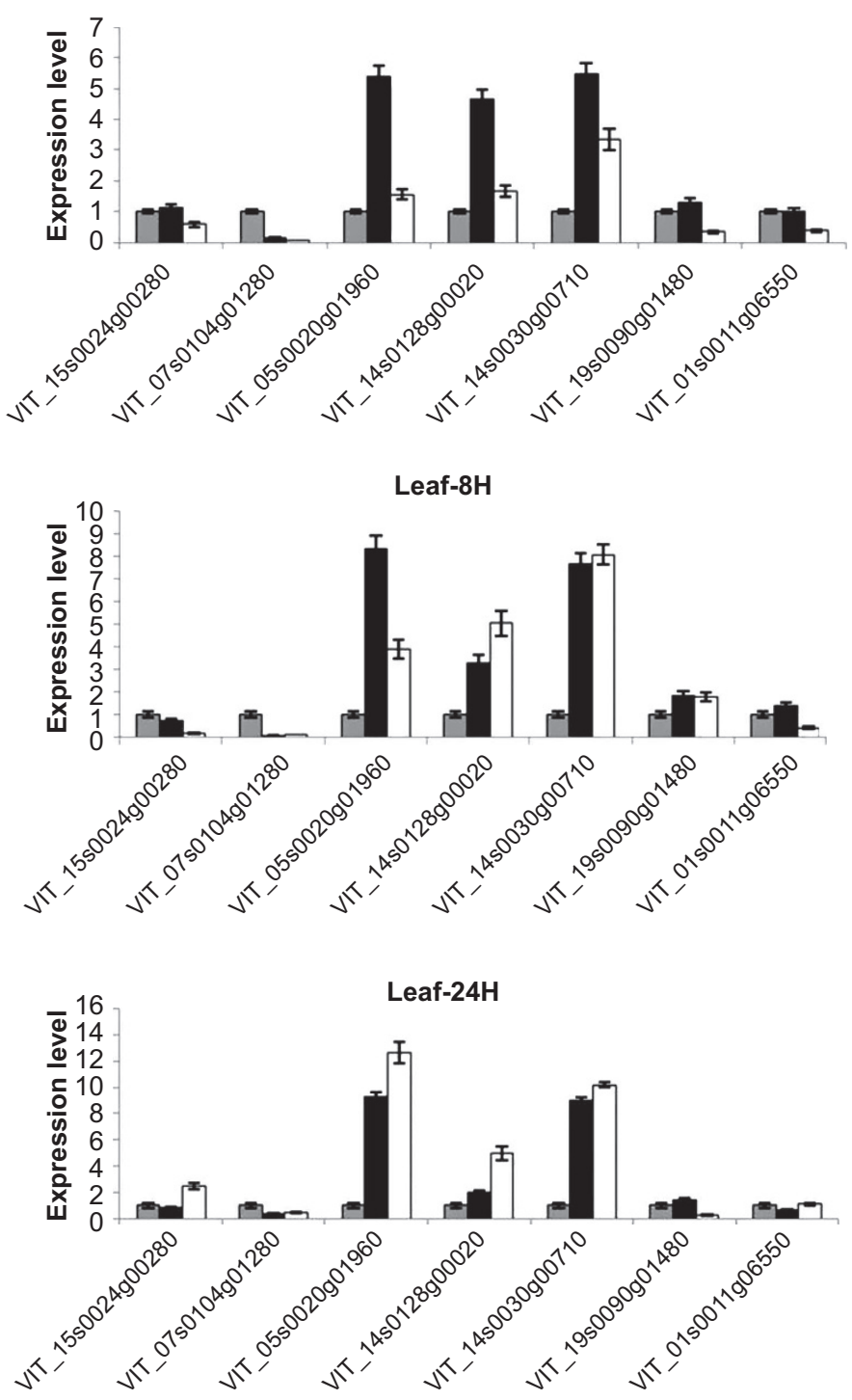

Leaf-4H

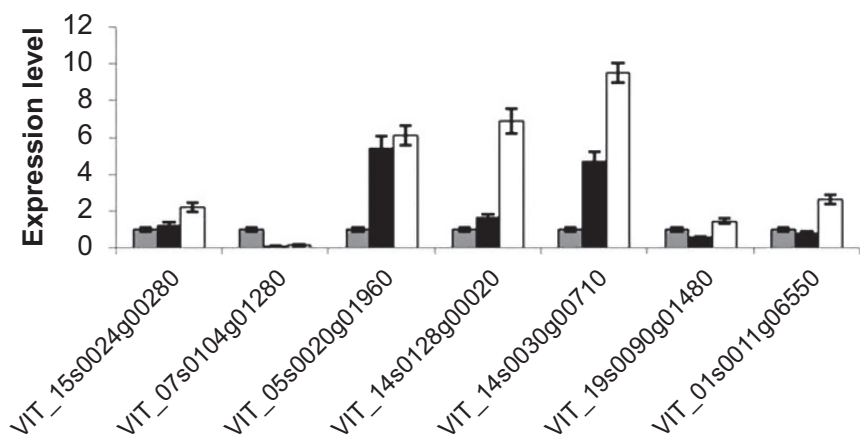

Leaf-12H
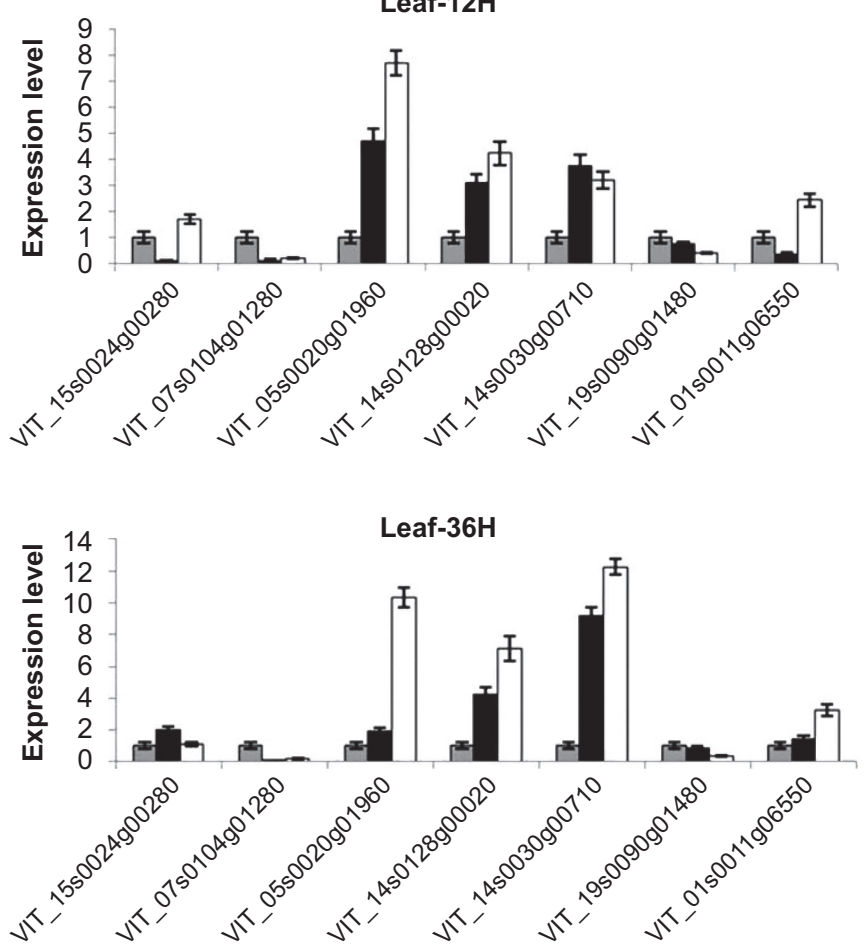

PEG

$\mathrm{NaCl}$

Figure 4. qPCR analysis of the expression of VviCPA1 genes in different organs of grapevine. Gene expression levels in leaves (a), stems (b), and roots $(\mathbf{c})$. The values are expressed as the mean $\pm \mathrm{SD}(n=3)$. 
that the roots may not tolerate, the stress would be partially transferred from roots to leaves, as suggested by the REL decrease in roots and increase in leaves $(1-8 \mathrm{~h}$ at $250 \mathrm{mM} \mathrm{NaCl}$, and $8-12 \mathrm{~h}$ at $120 \mathrm{mM} \mathrm{NaCl})$. We inferred that there was a $\mathrm{NaCl}$ defense mechanism in grapevine root, which was also proposed by Antcliff. ${ }^{17}$ Based on these results, we chose $250 \mathrm{mM} \mathrm{NaCl}$ as the stress treatment in the qPCR experiments and ion concentration analysis.

Ion concentration analysis

The effects of $250 \mathrm{mM} \mathrm{NaCl}$ on ion concentrations in different tissues are shown in Figure 2A. Concentrations of $\mathrm{Na}^{+}$increased in leaves, stems, and roots, and the $\mathrm{Na}^{+}$concentration changes were less significant in leaves than in roots and stems (Figure 2Aa). $\mathrm{Na}^{+}$levels were higher in roots than in stems, with the lowest $\mathrm{Na}^{+}$concentration in the leaves (Figure 2A-a). Roots are considered to be the main organ for $\mathrm{Na}^{+}$accumulation, and stems can control the transport of $\mathrm{Na}^{+}$to leaves. The concentration of $\mathrm{K}^{+}$in all tissues was decreased (Figure 2A-b). Especially in roots, the $\mathrm{K}^{+}$concentration increased first and then decreased. Leaves showed the opposite trend to that in roots, which suggests that $\mathrm{K}^{+}$was transported to leaves as the stress intensified (Figure $2 \mathrm{~A}-\mathrm{b}$ ). $\mathrm{Ca}^{++}$concentrations showed a significant increase after $24 \mathrm{~h}$ in roots, but they varied greatly in leaves between $8 \mathrm{~h}$ and $24 \mathrm{~h}$ (a significant decrease first, then a significant increase) (Figure $2 \mathrm{~A}-\mathrm{C}$ ). In stems, $\mathrm{Ca}^{++}$showed a significant decrease after $12 \mathrm{~h}$ (Figure $2 \mathrm{~A}-\mathrm{c}$ ). The trend of $\mathrm{Mg}^{++}$ change was similar to the $\mathrm{K}^{+}$change in roots (Figure $2 \mathrm{~A}-\mathrm{d}$ ).

In addition, the $\mathrm{K}^{+} / \mathrm{Na}^{+}$ratio (Figure $2 \mathrm{~B}$ ) decreased over time in roots and stems; however, in leaves it was the highest before $8 \mathrm{~h}$. This indicates that although the absorption of $\mathrm{Na}^{+}$did not decline, the transportation of $\mathrm{Na}^{+}$to leaves was restricted. In roots and stems, there were significant negative correlations between $\mathrm{Na}^{+}$ and $\mathrm{K}^{+}$in roots $(r=-0.826, p<0.05)$ and in stems $(r=-0.944, p<$ 0.01 ); however, there was no correlation between $\mathrm{Na}^{+}$and $\mathrm{K}^{+}$concentration in leaves. We inferred that there was competition b

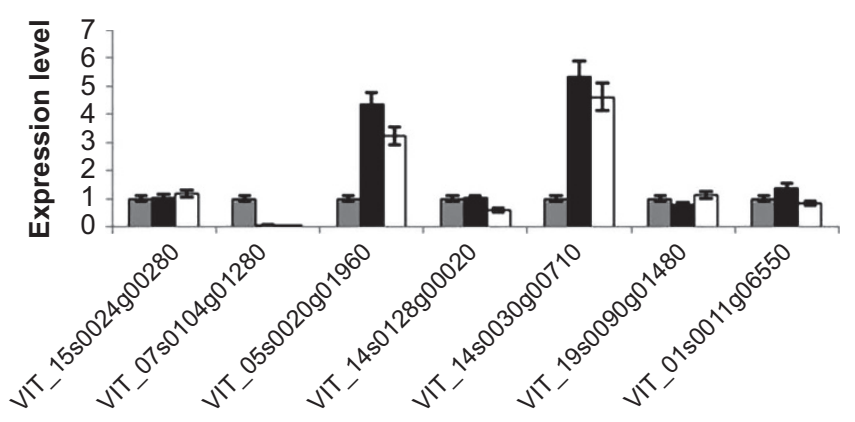

Stem-8H

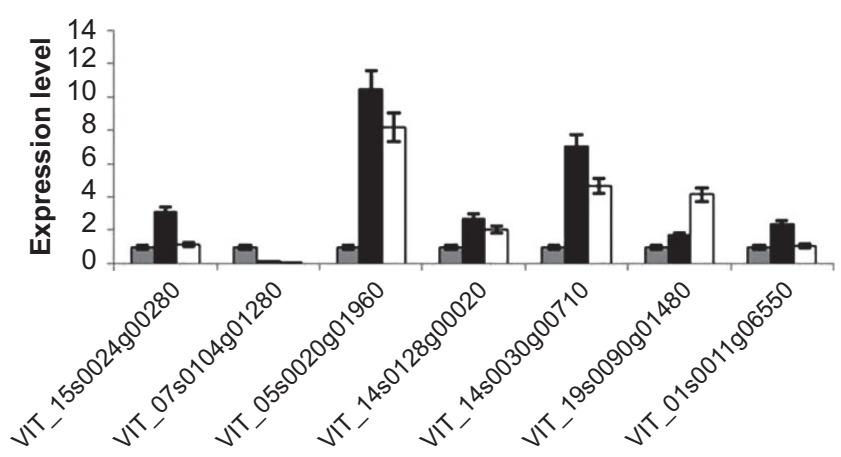

Stem-24H

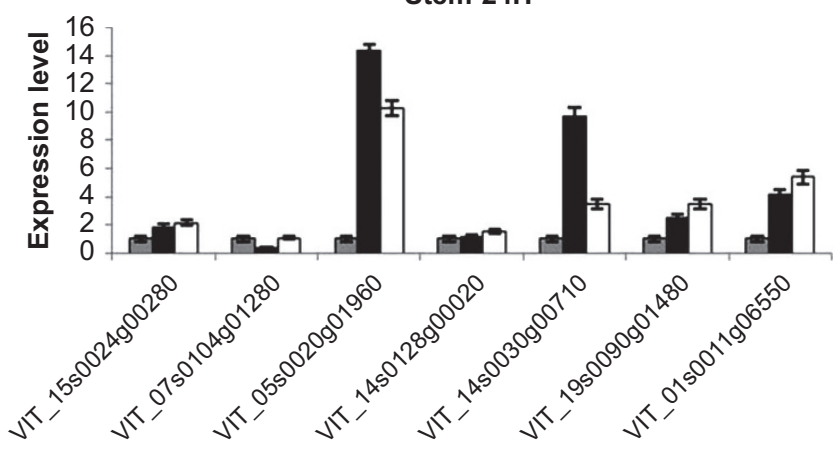

Stem-4H

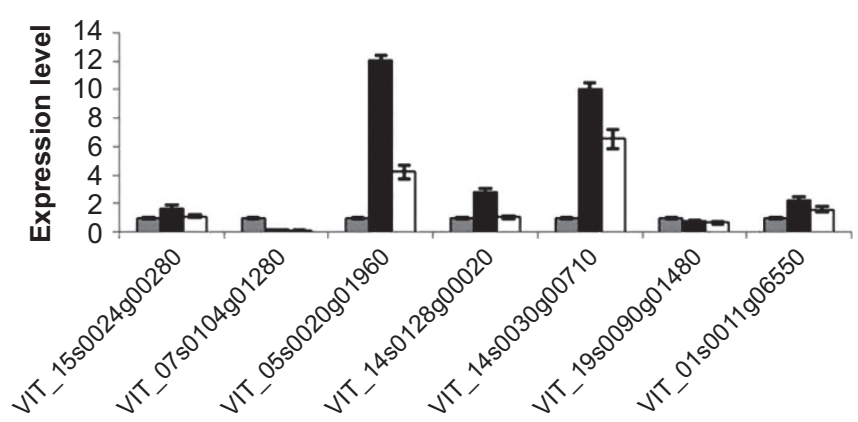

Stem-12H

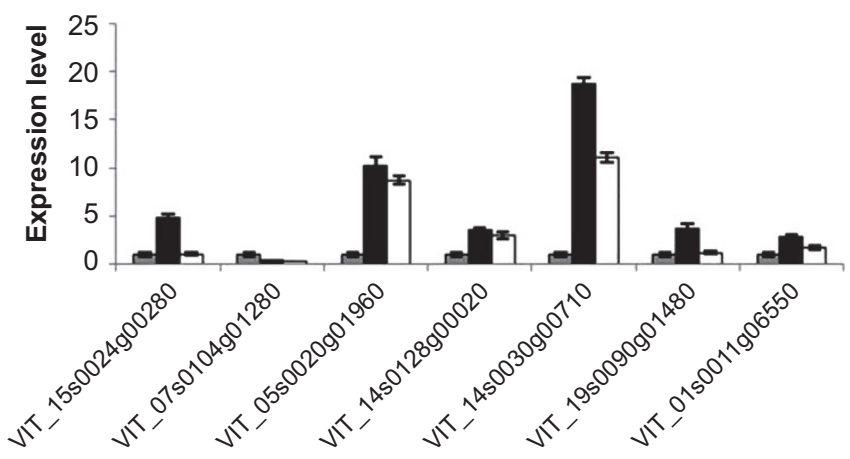

Stem-36H

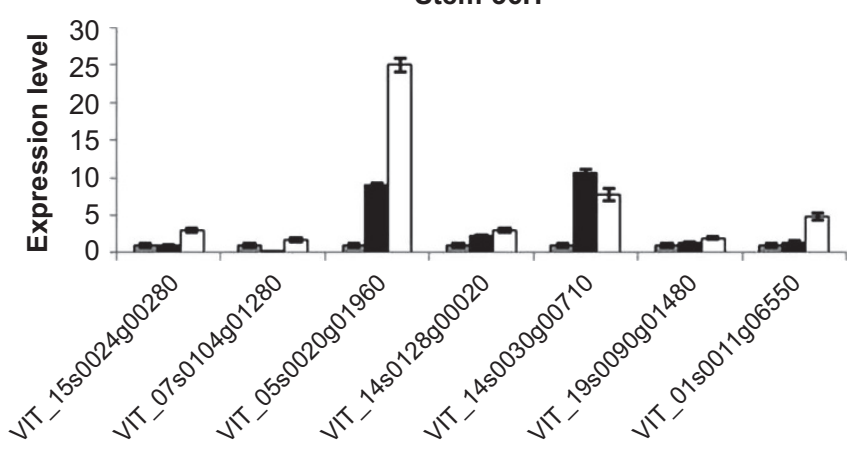

Figure 4b. Continued 
between $\mathrm{Na}^{+}$and $\mathrm{K}^{+}$in the absorption and transportation responses to $\mathrm{NaCl}$ stress in grapevine.

\section{VviCPA1 gene expression}

CPA1 genes have been widely demonstrated to be involved in $\mathrm{NaCl}$ responses and tolerance in plants, ${ }^{35-39}$ but limited information on CPA1 gene expression in response to $\mathrm{NaCl}$ stress is available in grapevine. A previous global gene expression analysis of $V$. vinifera $C V$ 'Cabernet Sauvignon' in $120 \mathrm{mM} \mathrm{NaCl}$, osmotic stress adjusted by polyethylene glycol (PEG) or cold $\left(5{ }^{\circ} \mathrm{C}\right)$ stress prior to the wholegenome sequence release $^{40}$ showed three responsive CPA1 genes: three CPA1s (VIT_05s0020g01960, VIT_14s0030g00710, VIT_ 19s0090g01480) and three CPA2s (VIT_08s0007g00020, VIT_ 15s0046g03390, VIT_02s0025g00820). Figure 3 shows the expression pattern of the VviCPA1s, measured by qPCR, in response to short-term $\mathrm{NaCl}$ stress in three different grapevine tissues (root, stem, and mature leaf). Because $\mathrm{NaCl}$ stress also creates osmotic stress, we also treated grapevines with PEG6000 at osmolarity equivalent to $250 \mathrm{mM} \mathrm{NaCl}$.

All VviCPA1s except VIT_07s0104g01280 exhibited tissue-specific expression in response to the two treatments. VIT_07s0104g01280 showed similar expression trends in leaf, stem, and root tissues during either PEG or $\mathrm{NaCl}$ treatment from $0 \mathrm{~h}$ to $12 \mathrm{~h}$, but it showed a significant difference $(p<0.5)$ after $12 \mathrm{~h}$ in stems (Figure 3a). The majority of VviCPA1s exhibited low levels of expression in roots after both treatments, whereas VIT_19s0090g01480 showed significantly higher expression after $12 \mathrm{~h}$ in response to $\mathrm{NaCl}$ than in response to PEG treatment $(p<0.05)$ (Figure 3b). VIT_15s0024g00280, VIT_ 05s0020g01960, VIT_14s0030g00710, and VIT_01s0011g06550 showed different expression patterns after PEG and $\mathrm{NaCl}$ treatment among the three tissues (Figure $3 c-f)$. Some of the differences occurred only after $12 \mathrm{~h}$, such as that of VIT_07s0104g01280 (Figure 3a). However, VIT_14s0030g00710 exhibited similar trends in response to PEG and $\mathrm{NaCl}$ treatments among the three tissues (Figure 3e).
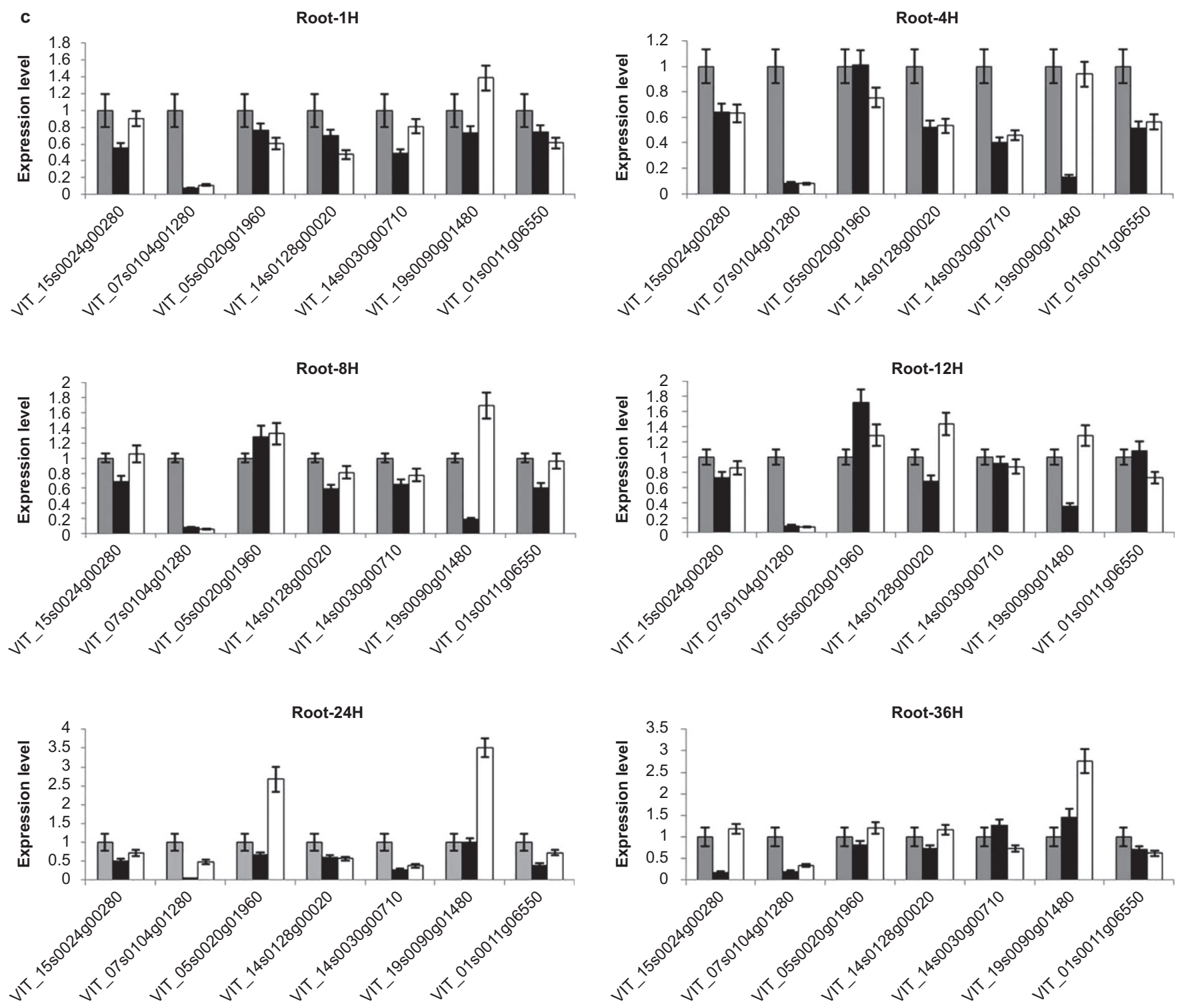

CK

Figure 4c. Continued 
Compared with the other VviCPA1s, VIT_05s0020g01960, VIT_14s0128g00020, and VIT_14s0030g00710 showed higher expression levels in leaves (Figure 4a), whereas VIT_05s0020g01960 showed the highest level of expression at $24 \mathrm{~h}$ after $\mathrm{NaCl}$ treatment, increasing nearly 13 -fold. Along with a previous report ${ }^{21}$ that VIT_14s0128g00020 is involved in the process of $\mathrm{K}^{+}$absorption, we inferred that VIT_05s002 Og01960, VIT_14s0128g00020, and VIT_14s0030g00710 participate in the movement of monovalent cations (mainly $\mathrm{K}^{+}$and $\mathrm{Na}^{+}$), like other plant NHX-type genes. ${ }^{41}$ In stems (Figure 4b), VIT_05s0020g01960 and VIT_01s0011g06550 exhibited higher expression levels in later periods of $\mathrm{NaCl}$ stress than those of PEG treatment. The highest expression level in stems was that of VIT_05s0020g01960 in response to $\mathrm{NaCl}$ at 36 h, which was nearly 25 -fold that of the control. Because $\mathrm{Na}^{+}$is reabsorbed and transferred by xylem parenchyma cells, ${ }^{42,43}$ we inferred that VIT_05s0020g01960 may be more highly expressed in xylem parenchyma cells for $\mathrm{Na}^{+}$transfer. In roots, the highest level of expression was observed for VIT_19s0090g01480 in response to $\mathrm{NaCl}$ at $24 \mathrm{~h}$ with only a 3.5-fold increase of expression, and its expression level was higher in response to $\mathrm{NaCl}$ than in response to PEG at any time of treatment (Figure 4c). Therefore, VIT_19s0090g01480 was closely associated with the response to $\mathrm{NaCl}$ in roots. After $\mathrm{NaCl}$ treatment, the expression level of most VviCPA1s except VIT_19s0090g01480 was relatively low in roots (Figure 4c), whereas the ion content profiles showed that $\mathrm{Na}^{+}$primarily accumulated in roots (Figure 2A-a), and REL changed greatly in roots (Figure 1).

Because there was no linear relationship between $\mathrm{REL}$ and $\mathrm{Na}^{+}$, according to the orthologous relationship of VIT_19s0090g01480 with characterized genes in other species, like PeNHXs in Populus, ${ }^{36}$ we inferred that VIT_19s0090g01480 may transport $\mathrm{Na}^{+}$ into the root vacuoles to alleviate $\mathrm{Na}^{+}$toxicity in other organs. After $\mathrm{NaCl}$ treatment for $24 \mathrm{~h}$, the expression level of VIT_05s0020g01960 was up-regulated to its highest level in stems (Figure 4c). Therefore, we concluded this may be one of the reasons why REL appeared to decline between $24 \mathrm{~h}$ and $36 \mathrm{~h}$, during which time the expression of VIT_05s0020g01960 appeared to increase.

\section{SUMMARY}

Our study systemically determined the expression of grapevine CPA1 gene family members, REL values, and changes of ion concentrations during the first $36 \mathrm{~h}$ of osmotic stress (exerted by PEG) or $\mathrm{NaCl}$ stress in different organs. The seven CPA 1 family members diverged into two groups in response to $\mathrm{NaCl}$. Five genes, VIT_14s0128g00020, VIT_14s0030g00710,VIT_01s0011g06550,VIT_07s0104g01280, and VIT_15s0024g00280, appear to play minor or no roles in response to short-term $\mathrm{NaCl}$ stress because of their low expression. The other two genes, VIT_19s0090g01480 and VIT_05s0020g01960, have subfunctionalized in the evolutionary history and appear to function in concert to modulate the responses to $\mathrm{NaCl}$ stress in different tissues and in different stress stages. VIT_19s0090g01480 was induced strongly by $\mathrm{Na}^{+}$as the first responder in roots. After $\mathrm{NaCl}$ treatment for $24 \mathrm{~h}$, the expression level of VIT_05s0020g01960 was up to the highest level in roots in correspondence with the REL, whereas VIT_05s0020g01960 was highly induced in stem and leaf tissues in later stages in correspondence with the REL decrease in roots, suggesting that

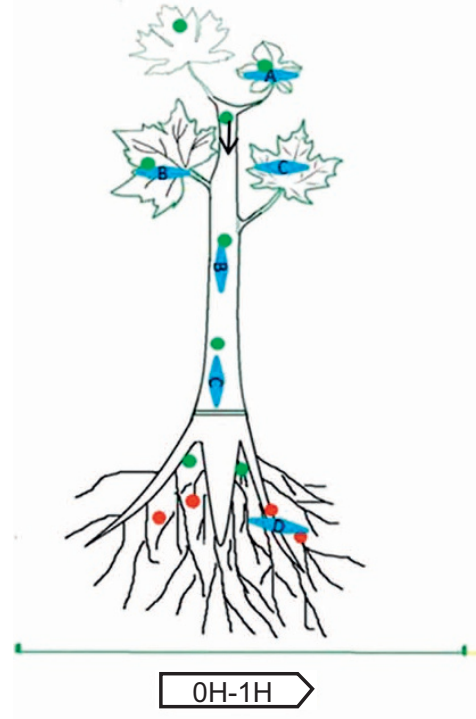

Leaf: PM was not damaged; REL had no change; $\mathrm{K}^{+}$decreased; $\mathrm{Na}^{+}$had no change; The expressions of Genes A, B, C were upregulated.

Stem: $\mathrm{K}^{+}$decreased; $\mathrm{Na}^{+}$had no change; Genes B,C had a high expression levels.

Root: PM was damaged; REL certainly raised. $\mathrm{K}^{+}$and $\mathrm{Na}^{+}$increased; Gene D had a high expression levels.

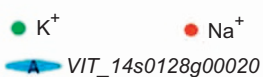
$\mathrm{Na}^{+}$

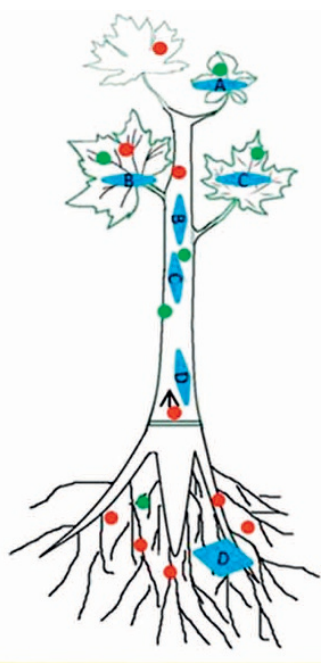

$1 \mathrm{H}-8 \mathrm{H}$

Leaf: PM was damaged; REL increased; $\mathrm{Na}^{+}$increased; $\mathrm{K}^{+}$had not change; Genes A,B,C still keep high expression.

Stem: $\mathrm{Na}^{+}$begin accumulating; $\mathrm{K}^{+}$keep decreasing; Genes B and C keep high expression levels; Gene D also participated.

Root: REL gradually restored; $\mathrm{K}^{+}$ decreased; $\mathrm{Na}^{+}$keep accumulating; Gene D was more active.

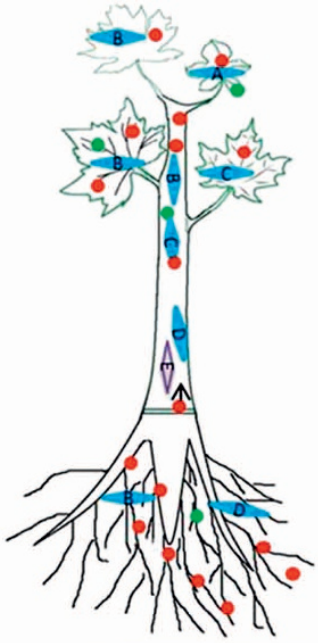

$8 \mathrm{H}-24 \mathrm{H}$

Leaf: REL always increased; $\mathrm{Na}^{+}$keep accumulating. Genes A,B,C keepup regulation, especially Gene $B$.

Stem: $\mathrm{Na}^{+}$keep accumulated; Genes B and $C$ keep high expression; Genes $D$ and $E$ had high expression.

Root: $\mathrm{Na}^{+}$still accumulated; REL increased again. Gene D keep more active, and Gene B had a high expression level.

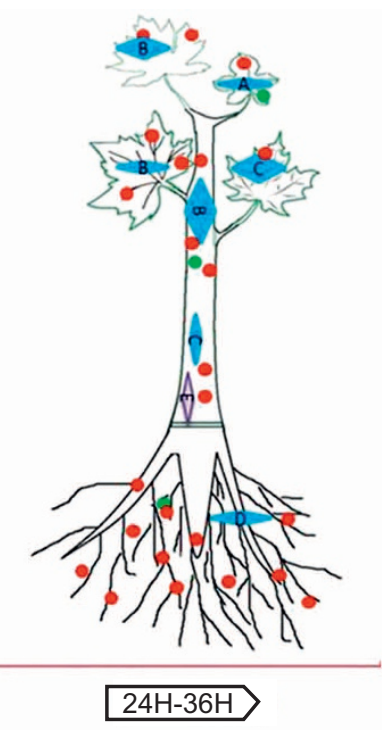

Leaf: $\mathrm{Na}^{+}$accumulated ;REL keep increasing; Stress was getting worse; Genes A,B,C keep high express levels.

Stem: $\mathrm{Na}^{+}$accumulated; Genes B and $\mathrm{C}$ keep high express ion levels.

Root: $\mathrm{Na}^{+}$still accumulated; REL restored a little, but still high; Gene D still keep high expression levels.

Figure 5 A summary of sequential physiological events and VviCPA1 gene involvement during the first $36 \mathrm{~h}$ of $\mathrm{NaCl}$ treatment of in vitro grapevine plants. 
VIT_05s0020g01960 is involved $\mathrm{Na}^{+}$transport from roots to stem and leaf tissue.

Based on the expression profiles in different organs and various stages during the first $36 \mathrm{~h}$ and on the ion concentrations and REL in various tissues, we summarized a sequence of physiological events and VviCPA1 gene participation during the first $36 \mathrm{~h}$ of $\mathrm{NaCl}$ treatment of in vitro grapevine plants, with details described in the legend of Figure 5.

\section{ACKNOWLEDGMENTS}

This project was funded by the National Agriculture Ministry "948 Project" (\#2011-G21), China and by the Priority Academic Program Development of Modern Horticultural Science in Jiangsu Province, China.

\section{AUTHORS' RESPONSIBILITIES}

Yuanchun Ma and Jiaoyang Wang performed the main experiment, Yuanchun Ma and Yan Zhong wrote the main manuscript text and Yuanchun Ma and Fang Geng prepared Figures 1-5. Grant R. Cramer was mainly responsible for modifying the article's language and grammar; Zong-Ming (Max) Cheng designed the experiment, provided financial support and revised the manuscript.

\section{REFERENCES}

1 Cramer G, Urano K, Delrot $S$ et al. Effects of abiotic stress on plants: a systems biology perspective. BMC Plant Biol 2011; 11: 1-14.

2 Wang W, Vinocur B, Altman A. Plant responses to drought, salinity and extreme temperatures: towards genetic engineering for stress tolerance. Planta 2003; 218 : $1-14$

3 Munns R, Tester M. Mechanisms of salinity tolerance. Annu Rev Plant Biol 2008; 59: 651-681.

4 Zhu JK. Regulation of ion homeostasis under salt stress. Curr Opin Plant Biol 2003; 6 : 441-445.

5 Hasegawa PM. Sodium $(\mathrm{Na}+$ ) homeostasis and salt tolerance of plants. Environ Exp Bot 2013; 92: 19-31.

6 Tester M, Davenport R. $\mathrm{Na}+$ tolerance and $\mathrm{Na}+$ transport in higher plants. Ann Bot 2003; 91: 503-527.

7 Bassil E, Blumwald E. The ins and outs of intracellular ion homeostasis: NHX-type cation/H+ transporters. Curr Opin Plant Biol 2014; 22: 1-6.

8 Maser $\mathrm{P}$, Thomine S, Schroeder Jl et al. Phylogenetic relationships within cation transporter families of Arabidopsis. Plant Physiol 2001; 126: 1646-1667.

9 Brett CL, Donowitz M, Rao R. Evolutionary origins of eukaryotic sodium/proton exchangers. Am J Physiol Cell Physiol 2005; 288: C223-C239.

10 Fujisawa M, Ito M, Krulwich TA. Three two-component transporters with channellike properties have monovalent cation/proton antiport activity. Proc Natl Acad Sci U S A 2007; 104: 13289-13294.

11 Aradhya MK, Dangl GS, Prins BH et al. Genetic structure and differentiation in cultivated grape, Vitis vinifera L. Genet Res 2003; 81: 179-192.

12 Bouby L, Figueiral I, Bouchette A et al. Bioarchaeological insights into the process of domestication of grapevine (Vitis vinifera L.) during Roman times in Southern France. PLoS One 2013; 8: e63195.

13 Walker RR, Blackmore DH, Clingeleffer PR et al. Rootstock effects on salt tolerance of irrigated field-grown grapevines (Vitis vinifera L. cv. Sultana). 1. Yield and vigour inter-relationships. Aust J Grape Wine Res 2002; 8: 3-14.

14 Shani U, Waisel Y, Eshel A et al. Responses to salinity of grapevine plants with split root systems. New Phytol 1993; 124: 695-701.

15 Hawker JS, Walker RR. The effect of sodium chloride on the growth and fruiting of Cabernet Sauvignon vines. Am J Enol Viticult 1978; 29: 172-176.

16 Gil M, Esteruelas M, González E et al. Effect of two different treatments for reducing grape yield in Vitis vinifera cv Syrah on wine composition and quality: berry thinning versus cluster thinning. J Agr Food Chem 2013; 61: 4968-4978.

17 Antcliff AJ, Newman RP, Barrett HC. Variation in chloride accumulation in some American species of grapevine. Vitis 1983; 22: 357-362.

18 Oki LR, Lieth JH. Effect of changes in substrate salinity on the elongation of Rosa hybrida L. 'Kardinal' stems. Sci Hortic 2004; 101: 103-119.

19 Hopper DW, Ghan R, Cramer, GR. A rapid dehydration leaf assay reveals stomatal response differences in grapevine genotypes. Hort Res 2014; 1: 2.
20 Hanana M, Cagnac O, Yamaguchi $\mathrm{T}$ et al. A grape berry (Vitis vinifera L.) cation/proton antiporter is associated with berry ripening. Plant Cell Physiol 2007; 48: 804-811.

21 Chanroj S, Wang G, Venema K et al. Conserved and diversified gene families of monovalent cation $/ \mathrm{h}(+)$ antiporters from algae to flowering plants. Front Plant Sci 2012; 3: 25 .

22 Ma Y, Wang J, Zhong Y, Grant RC et al. Genome-wide analysis of the cation/ proton antiporter (CPA) super family genes in grapevine (Vitis vinifera L.). Plant Omics J 2015; 8: 300-311.

23 Epstein E. Mineral nutrition of plants: principles and perspectives. Hoboken: John Wiley \& Sons Ltd, 1972: 325-344.

24 Blum A, Ebercon A. Cell membrane stability as a measure of drought and heat tolerance in wheat. Crop Sci 1981; 21: 43-47.

25 Lutts S, Kinet JM, Bouharmont J. NaCl-induced senescence in leaves of rice (Oryza sativa L) cultivars differing in salinity resistance. Ann Bot 1996; 78: 389-398.

26 Flint HL, Boyce BR, Beattie DJ. Index of injury - a useful expression of freezing injury to plant tissues as determined by the electrolytic method. Can J Plant Sci 1967; 47: 229-230.

27 Schmidt AC, Reisser W, Mattusch J, Popp P, Wennrich R. Evaluation of extraction procedures for the ion chromatographic determination of arsenic species in plant materials. J Chromatogr A 2000; 889: 83-91.

28 Krachler M, Mohl C, Emons $\mathrm{H}$ et al. Influence of digestion procedures on the determination of rare earth elements in peat and plant samples by USN-ICP-MS. $J$ Anal Atom Spectrom 2002; 17: 844-851.

29 Krupp E, Milne B, Mestrot A et al. Investigation into mercury bound to biothiols: structural identification using ESI-ion-trap MS and introduction of a method for their HPLC separation with simultaneous detection by ICP-MS and ESI-MS. Anal Bioanal Chem 2008; 390: 1753-1764.

30 Chang S, Puryear J, Cairney J. A simple and efficient method for isolating RNA from pine trees. Plant Mol Biol Rep 1993; 11: 113-116.

31 Gonzalez-Mendoza D, Moreno AQ, Zapata-Perez O. An improved method for the isolation of total RNA from Avicennia germinans leaves. Z Naturforsch C 2008; 63: 124-126.

32 Wang M, Vannozzi A, Wang G, et al. Genome and transcriptome analysis of the grapevine (Vitis vinifera L.) WRKY gene family. Hort Res 2014; 1:14016.

33 Reid KE, Olsson N, Schlosser J et al. An optimized grapevine RNA isolation procedure and statistical determination of reference genes for real-time RT-PCR during berry development. BMC Plant Biol 2006; 6: 27.

34 Livak KJ, Schmittgen TD. Analysis of relative gene expression data using real-time quantitative PCR and the 2(T)(-Delta Delta C) method. Methods 2001; 25: 402-408.

35 Galvez FJ, Baghour M, Hao G et al. Expression of LeNHX isoforms in response to salt stress in salt sensitive and salt tolerant tomato species. Plant Physiol Biochem 2012; 51: 109-115.

$36 \mathrm{Ye} \mathrm{CY}$, Zhang HC, Chen JH et al. Molecular characterization of putative vacuolar $\mathrm{NHX}$-type $\mathrm{Na}+/ \mathrm{H}+$ exchanger genes from the salt-resistant tree Populus euphratica. Physiol Plant 2009; 137: 166-174.

37 Fukuda A, Nakamura A, Tagiri A et al. Function, intracellular localization and the importance in salt tolerance of a vacuolar $\mathrm{Na}+/ \mathrm{H}+$ antiporter from rice. Plant Cell Physiol 2004; 45: 146-159.

38 Xia T, Apse MP, Aharon GS, Blumwald E. Identification and characterization of a $\mathrm{NaCl}$-inducible vacuolar $\mathrm{Na}+/ \mathrm{H}+$ antiporter in Beta vulgaris. Physiol Plant 2002; 116: 206-212.

39 Zörb C, Noll A, Karl S et al. Molecular characterization of $\mathrm{Na}+/ \mathrm{H}+$ antiporters $(\mathrm{ZmNHX})$ of maize (Zea mays L.) and their expression under salt stress. J Plant Physiol 2005; 162: 55-66.

40 Cramer G, Ergül A, Grimplet J et al. Water and salinity stress in grapevines: early and late changes in transcript and metabolite profiles. Funct Integr Genomics 2007; 7: 111-134.

41 Pardo JM, Cubero B, Leidi EO et al. Alkali cation exchangers: roles in cellular homeostasis and stress tolerance. J Exp Bot 2006; 57: 1181-1199.

42 Kramer D, Läuchli A, Yeo AR et al. Transfer cells in roots of Phaseolus coccineus: ultrastructure and possible function in exclusion of sodium from the shoot. Ann Bot 1977; 41: 1031-1040

43 Yeo AR, Kramer D, Liuchli A et al. Ion distribution in salt-stressed mature Zea mays roots in relation to ultrastructure and retention of sodium. J Exp Bot 1977; 28: 17-29.

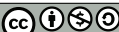

This license allows readers to copy, distribute and transmit the Contribution as long as it is attributed back to the author. Readers are permitted to alter, transform or built upon the Contribution as long as the resulting work is then distributed under this or a similar license. Readers are not permitted to use the Contribution for commercial purposes. Please read the full legal code for further details at http://creativecommons.org/licenses/by-nc-sa/3.0/legalcode 